\title{
Urban Communities as a Social Space for Child Abuse
}

\author{
Mihai-Bogdan Iovu ${ }^{1}$, Maria Roth ${ }^{1}$ \\ ${ }^{1}$ Babeş-Bolyai University of Cluj-Napoca, Department of Social Work,128 21 Decembrie 1989 Bld., 400604 Cluj-Napoca, Romania
}

KEYWORDS

Child abuse

Neglect

Urban areas

Social disorganisation

\section{ABSTRACT}

Statement of problem: The rate at which children are maltreated is one of the most sensitive measures of demographic, social, and economic conditions. Maltreatment may differ markedly in terms of an area's socio-demographic and economic makeup and this phenomenon needs to be studied in a structural context. This study employs a social disorganization perspective to identify the most reliable structural factors of child maltreatment for children aged 10 to 18 years in Vâlcea County. Method: ICAST-CH, an instrument developed by the International Society for Prevention Child Abuse and Neglect in order to assess child maltreatment's rates in a unitary way in different countries. It was applied to 1142 children in Vâlcea's urban areas. Results: child abuse is positive correlated to high rates of community violence and negative correlated with community resources. The parents' education and occupation status is involved in explaining high rates of child abuse in different manners. Conclusion: the urban areas are diverse spaces in terms of variables that influence child abuse. Future studies in the subject of structural child abuse would need to be done in more urban areas in order to find some additional patterns of the phenomenon.

\section{Introduction}

As a consequence of the importance of social-psychological environment for children, child maltreatment has been the subject of controversy and concern (Smith, Ireland and Thornberry 2005). The basis for

\footnotetext{
* Contact addresses: iovu_mbogdan@yahoo.com (Mihai-Bogdan Iovu), mroth@socasis.ubbcluj.ro (Maria Roth)
} 
and the pervasiveness of child maltreatment have been researched extensively in recent years, especially in the light of the increased number of cases of abuse and neglect in more developed countries. But even in the less developed countries, the phenomenon is still present on the public agenda. Globally, over 40 million children aged below 15 are victims of violence every year, but according to UN Study (2006) 97\% of them do not benefit from any legal protection as adults do. Only 17 countries worldwide have forbidden physical aggression while in the rest of them it is still legal. At European level, the European Commission recommendations ${ }^{1}$ advise elimination of every physical aggression toward children, but on September $28^{\text {th }}, 2008$ only 15 states out of the 27th from EU (including Romania from 2004) had banned it through specific legislation (Global Initiative to End All Corporal Punishment of Children, 2008) $)^{2}$.

Longitudinal data for Romania are hard to find consider the newly established National Authority for the Protection of Family and Children's Rights (NAPFCR) 3 collects data only from 2007. For that year, a total of 9773 cases was recorded, out of which more than half (5976) were neglected. For 2008 there is a rise of $19.11 \%$ cases, the total being 11641. The upward trend continues in 2009, even if the rise is insignificant (11686). Other institutions like Telefonul copilului show the same ascending line. Compared to 2008, in 2009 there was a raise of $74.8 \%$ of received calls.

A study conducted by Babeş-Bolyai University and financed by UNICEF$^{4}$ showed that out of the total number of cases reported to the General Direction for Social Assistance and Child Protection (GDSACP), the most frequent relate to physical abuse within the family $(82 \%)$, followed by

\footnotetext{
${ }^{1}$ Committee of Ministers recommendation 19 (2006) on policy to support positive parenting, Parliamentary Assembly Recommendation 1666 (2004) on a Europe-wide ban of corporal punishment of children, Parliamentary Assembly Recommendation 1778 (2007) on child victims: stamping out all forms of violence, exploitation and abuse

2 Although the UN report on violence proposed that by 2009 physical violence should be completely banned, by November 2009 only 25 states had succeeded (Sweden, Finland, Norway, Austria, Cyprus, Denmark, Latvia, Croatia, Bulgaria, Israel, Germany, Iceland, Ukraine, Romania, Hungary, Greece, Netherlands, New Zeeland, Portugal, Uruguay, Venezuela, Spain, Costa Rica, Moldova, Luxemburg), and two states have the decision of the Higher Court in this regard, but no specific legislation (Italy and Nepal).

${ }^{3}$ By the law 329/2009 and HG 385/26.11.2009, the National Authority for the Protection of Children's Rights (NAPCR) was restructured.

4 Child Abuse and Violence against Children - Services of Intervention (contract no. 30958/06.06.2008) - unpublished report.
} 
emotional abuse within the family (67\%) and severe physical and educational neglect (65\%). Meanwhile it is well acknowledged that official data do not necessarily reflect the real state of child abuse.

\section{Child abuse and community}

Two broad explanations of children's maltreatment have dominated the literature, one of which emphasizes the personal attributes of victims or of abusers, and the second which emphasizes structural conditions underlying child maltreatment. In the first case, researchers argue that abuse may vary by age, gender, poverty status and race/ethnicity, among other demographic and socio-economic factors. These variables may be attributes of the victims, or of the perpetrators. In contrast, others offer a "societal" explanation of child maltreatment, with a focus on social and economic inequalities that increase the likelihood of maltreatment (Gil 1970 apud. Krishnan and Morrison 1995). A considerable number of studies have shown that children's ecological contexts may serve as risk factors for experiencing child abuse and neglect. Contextual factors, including being from a low socioeconomic household, having several closely spaced siblings and living in an impoverished community with limited resources or with a high level of violence have been noted as significant risk factors for being maltreated. There has also been an increasing interest in understanding how the various contexts in which children live may influence the effects of maltreatment when it has already occurred, yet comparatively few studies have addressed this topic (Zielinski and Bradshaw 2006). This change of view begins from understanding child abuse not only as an individual or familial dysfunction, but more as a dysfunction of the community (Garbarino and Kostelny 1992).

Two major research traditions have influenced the thinking about the relationships between community and child maltreatment: one that focuses on social disorganization and the other on ecological-transactional development (Coulton et al. 2007). The first tradition, examines the relationship between geographic concentrations of social problems and social processes within neighbourhoods thought to contribute to social control, such as network ties, shared norms, collective efficacy, institutional resources, and routines. The strength of the social disorganization tradition is that it describes some of the specific social structures and processes within 
neighbourhoods that may be related to child maltreatment and other problems and provides some explanations as to how social structure and process are related. However, social disorganization theory provides little specificity about how these neighbourhood characteristics may influence children and families' behaviour and development. The second tradition, examines how child development and parenting are influenced by the environment, including neighbourhoods. The model views child maltreatment within a system of risk and protective factors interacting across four levels: the individual or ontogenetic level, the family or microsystem level, the exosystem (which includes neighbourhoods), and the social or macrosystem. The community context of child maltreatment proposed by Garbarino is a comprehensive framework composed of socioeconomic factors (e.g., economic resources), demographic factors (e.g., family and age structure of the population), ideological factors (e.g., values and attitudes about neighbourhood and community characteristics) and historical factors (developmental trends in the characteristics of community and individual relationships to local residence). Of the four factors, the last two are often difficult to realize because of the lack of questionnaire surveys and data. More recently, this model has been used to demonstrate reciprocal relationships between children's exposure to community violence, child maltreatment, and child functioning over time (Cicchetti and Valentino 2006). The strength of this approach is that it describes some of the specific ways the environment may influence the transactions between a parent and child and between a family and the neighbourhood. However, the ecological-transactional model provides limited explanation about how neighbourhood conditions and social processes influence these transactions and about how and why these neighbourhood conditions and processes occur.

By combining those two theories, child maltreatment is explained not by the particular influence of isolated factors, but by their interaction. It shows that violence against children is a multicausal phenomenon in which factors regarding child development and his personality interacts with parental factors, the transaction working at all individual, familial, interpersonal, organizational, and macrosocial levels (Roth 2005). Studies regarding urban communities and child maltreatment point out the idea of 
necessary and sufficient conditions of abuse/neglect. Necessary conditions are those that are created by individuals, while sufficient conditions are those that are already within the community as a datum (Krishnan and Morrison, 1995). Two kinds of factors are then studied:

- Structural (demographics, socio-economical status, family type, residency etc.) (Coulton et al. 2007);

- Process-based (social network, social cohesion) (Sampson, Morenoff and Gannon-Rowley 2002).

\section{Neighbourhood structural characteristics versus neighbourhood processes and child maltreatment}

Coulton and colab. (1995) identified that socio-economic factors of the community significantly correlate with the maltreatment rate in Cleveland, Ohio. Similar results were also obtained in other areas like Montgomery County, Maryland (Ernst 2001) and Missouri (Drake and Pandey 1996). All these findings replicate a pattern identified as early as in 1978 (Garbarino and Crouter 1978). European space is not an exception to that rule: Gilham and colab. (1998) found that the unemployment status of fathers correlate with maltreatment rate in Glasgow, Scotland. Still, the most consistent associations were with the income (Berger 2005), type of residency/property (Ernst 2000), unemployment rate (Freisthler 2004; Freisthler, Midanik and Gruenewald 2004), poverty rate (Berger 2005; Ernst 2000; Freisthler 2004). Using the factorial analysis, some studies have reached the conclusion that the higher the economical disadvantage of a community, the higher the child maltreatment rate is. Other structural factors that were previously analyzed were child-care burden (Coulton et al. 1995, 1999; Korbin et al. 2000), residential instability (Coulton et al. 1995; Ernst 2000, 2001), lower female labour force participation (Ernst 2000), overcrowding (Garbarino and Kostelny 1992; Scannapieco and Connel-Carrick 2006), and per capita density of alcohol and drug outlets (Freisthler et al. 2005). Other studies try not only to reveal general association but to identify relation with particular forms of child maltreatment. Drake and Pandey (1996) showed that the poverty level of the community is strongly associated to neglect and less to physical or sexual abuse. Similarly, Kim (2004) indicated that low economic status is associated to neglect and not to physical abuse. Ernst (2000) 
concluded that while the low economic resources are associated to physical abuse, sexual abuse and neglect, low social resources are associated to physical and sexual abuse and not to neglect. The availability of alcohol and drugs are correlated to physical abuse and the per capita density is correlated to neglect (Freisthler et al. 2004). As early as 1986 Zuravin talks about associations between overcrowding and neglect, and between residential instability and neglect, with less emphasis on abuse (1989). In terms of spatial dynamics, it seems that neglect is more related to spatial determinants than abuse (Drake and Pandey 1996; Kim 2004).

Structural factors do not solely explain the dynamic of child maltreatment. Some studies have tried to concentrate on process-based factors in urban communities. Garbarino and Sherman (1980) compared communities with high and low maltreatment rate, concluding that communities with a higher rate were characterized by low social cohesion and a higher level of stress. Similar results were obtained more recently (Guterman et al. 2009). Deccio and colab. (1994) conclude that differences between communities with high/low maltreatment rate are due to low social integration factors and not to the degree of economic disadvantage. Ernst (2001) suggests that it is not the higher rate of poverty that determines child maltreatment but the degree to which the members of the community relate to each other and help each other. Korbin and colab. (1998) showed in an ethnographic study that in communities with a low economic status, but with a high degree of social cohesion, the maltreatment rate was lower.

\section{Child abuse and community - current research question}

In this paper we will test a social disorganization explanation, in the trial of identifying the most accurate structural determinants of child maltreatment. We will focus only on urban areas because these are more diverse than rural ones and on Vâlcea County which became an industrialized county during the communist period. Its urbanicity level was strongly shaken by post-communist industrial restructuring. Nowadays its urbanicity level reaches $45.30 \%$ (National Institute of Social and Economic Statistics 2006) and according to official data it has one of the lowest child 
maltreatment rates in South-West Region (National Authority for the Protection of Child's Rights 2008).

Starting from the criteria of any relevant research paper (King, Keohane and Verba 2000), the hypothesis that we had in mind started from two key-points: (1) from the relevant literature we selected research questions that were previously tested in other contexts aiming to see the extent to which these are also applicable in Romanian context; (2) Romanian studies regarding child maltreatment are mostly descriptive in their nature, so we will try to offer a scientific explanation of the phenomenon in a specific social context. By combining these two arguments, the current paper fully satisfies the request of the significant contribution to a specific topic.

From the factors described by social disorganization theory we selected three that were the most used: community violence, residential mobility and (social) resources. Therefore, the hypothesis that we had in mind were as follows:

- Areas with an increased community violence rate are related with higher rates of self-reported child abuse. Starting from the study of Cicchetti and Valentino (2006), increased exposure to community does affect child and family functioning over time. Sampson and colab. (1997) identify the mutual social support as a key factor of community functioning and define it as the availability of members to action in their best interest. Areas with a high level of social support are characterized by low levels of violence (Kingston, Huizinga \& Elliot 2009). Therefore, we will use the level of community violence as an indirect measure of social support.

- Areas with a low residential stability are related with increased child abuse phenomenon. Residential mobility is one of the most incriminated factors in this theory (Coulton et al. 1995; Ernst 2000, 2001), proving that areas with increased mobility are characterized by increased level of child maltreatment.

- Areas with low social resources are related with increased child abuse. The social disadvantage of a community is associated to increased violence toward children. While Ernst (2000) concluded that low economic resources are associated to physical abuse, sexual abuse and neglect, low social resources are associated to physical and sexual abuse and not to neglect. 


\section{Methods}

\section{Source of data}

Data were collected between November 1 ${ }^{\text {st }}, 2008$ and January 31 2009. The total sample consisted of 1142 children from secondary and upper secondary schools from Vâlcea County. Their questioning about such a sensitive subject raised some methodological and ethical issues that need to be addressed accurately. Having few alternatives we choose the same methodological design from the study conducted in Cluj county in 1996 (Rotariu et al. 1996). The reasons are as follows: (a) considering our ageinterest most of the children are already enrolled in educational process; the ones who are not yet special cases and should be treated as such. Our investigation wanted to assess what is happening in the typical family. (b) from a certain age, children can be used as subjects in an inquiry because they have the ability to answer questions. More than that, because children are used to completing work sheets and have to do homework, the educational setting is a perfect environment for such an activity because completing the questionnaire will not be seen as a special activity, but a normal one. (c) grouping children in classes has the advantage of applying a great number of questionnaires in a shorter period of time. (d) this type of study is offering more guarantees for anonymity, so less distortional information is expected.

The sample is representative for the school population in urban areas, with a maximum error of +/-.02 (Lenth 2006). School's selection was based on the type and the level of centrality, assuring that we have children with different social, ethnic or school performances profiles. In the towns where it was possible (Rm. Vâlcea and Drăgăşani) we did not pick the top schools, and in the cities where there was only one school, we avoid elite classes.

Data were collected using the ICAST-CH (The ISPCAN Child Abuse Screening Tool - Child Version) questionnaire. The questionnaire measures violence against children and has been developed through a series of meetings and reviews conducted by the ISPCAN. This work has been conducted in conjunction with the UN Secretary General's Study on Violence against Children. The questionnaire was self administrated and the 
average time needed for completion was one hour. A formal agreement from the Vâlcea County School Inspectorate was obtained. Also an agreement from the school manager was obtained before the actual completion. Respondents were told that their responses would be treated anonymously.

\section{Sample Profile}

As shown in table 1, the sample was about evenly split between male and female students. The large majority of the sample indicated that they were Romanian and Orthodox. There were more middle school children in the sample than from high schools, probably due the fact that there were more $5-8^{\text {th }}$ grade students in the classes at the time of completion. The majority of the sample also indicated that they came from a typical family structure (with both parents present and married).

Table 1. Sample profile $(N=1142)$

\begin{tabular}{|c|c|}
\hline Characteristic & Percentage (n) \\
\hline \multicolumn{2}{|l|}{ Gender } \\
\hline Male & $48.5(554)$ \\
\hline Female & $51.5(588)$ \\
\hline \multicolumn{2}{|l|}{ School level } \\
\hline Middle & $55.4(633)$ \\
\hline Hgh & $44.6(509)$ \\
\hline \multicolumn{2}{|l|}{ Family type } \\
\hline Parents are married & $77.6(882)$ \\
\hline Parents are living together but are not married & $0.2(2)$ \\
\hline Parents are divorced & $7.5(85)$ \\
\hline One of the parents is dead & $2.1(24)$ \\
\hline One of the parents is at work outsice the country & $6.4(73)$ \\
\hline One of the parents is not my natural parent & $6.2(71)$ \\
\hline \multicolumn{2}{|l|}{ Religion } \\
\hline Orthodox & $99.6(1138)$ \\
\hline Other & $0.4(4)$ \\
\hline \multicolumn{2}{|l|}{ Racelethnicity } \\
\hline Romanian & $99.7(1139)$ \\
\hline Rroma & $0.3(3)$ \\
\hline \multicolumn{2}{|l|}{ Income } \\
\hline$\angle 500 R O N$ & $3.6(39)$ \\
\hline $502-1000$ RON & $15.2(165)$ \\
\hline $1001-1500 R O N$ & $16.9(183)$ \\
\hline $1501-2000 R O N$ & $24.5(265)$ \\
\hline$>2002$ RON & $39.7(430)$ \\
\hline \multicolumn{2}{|l|}{ Occupation status - father } \\
\hline Worling full-time & $84.7(932)$ \\
\hline Working part-time & $4.9(54)$ \\
\hline Looking for job & $4.1(45)$ \\
\hline Doe not work & $6.3(69)$ \\
\hline \multicolumn{2}{|l|}{ Occupation status - mother } \\
\hline Working full-time & $74.3(837)$ \\
\hline Working part-time & $6.1(69)$ \\
\hline Looking for job & $3.4(380)$ \\
\hline Doe not work & $16.2(183)$ \\
\hline \multicolumn{2}{|l|}{ Educational status - father } \\
\hline Below highschool & $8.7(98)$ \\
\hline Highschool & $62.8(708)$ \\
\hline Uhiversity studies & $24(271)$ \\
\hline Post university studies & $4.4(50)$ \\
\hline \multicolumn{2}{|l|}{ Educational status - mother } \\
\hline Below highschool & $6.4(72)$ \\
\hline Highschool & $63.2(715)$ \\
\hline University studies & $24.3(279)$ \\
\hline Post university studies & $6.1(69)$ \\
\hline
\end{tabular}




\section{Measures}

Seven measures, including four independent variables and three outcome measures were used to examine the relationship between the community structure and child abuse within the family. Each measure was considered an index with multiple indicators assessing the underlying construct (DeVellis 1991).

\section{Independent variables}

Community violence $(V C)$ index focused violent behaviours that might take place within the community (e.g. humiliation, physical aggressions, fights, threats, and robberies). The response categories were 'in the last month', 'in the last 6 months', 'ever' and 'never'. Each response was recoded from 1 to 4 . By adding the scores from each question, a total score for $\mathrm{CV}$ was generated. The Cronbach' alpha for the CV scale was 0.8528 .

Table 2. Descriptive Statistics for Community Violence

\begin{tabular}{lcccc}
\hline $\begin{array}{l}\text { While on street in your city, you } \\
\text { or other person had ever been. }\end{array}$ & $\begin{array}{c}\text { In the last } \\
\text { month }\end{array}$ & $\begin{array}{c}\text { In the last } 6 \\
\text { months }\end{array}$ & Ever & Never \\
\hline loumiliated, cursed & $719(65.7 \%)$ & 0 & $304(27.8 \%)$ & $71(6.5 \%)$ \\
\hline lit, beaten & $786(71.9 \%)$ & 0 & $276(25.3 \%)$ & $31(2.8 \%)$ \\
\hline in conflict, fights & $648(59.4 \%)$ & 0 & $373(34.2 \%)$ & $70(6.4 \%)$ \\
\hline threatened & $776(71.5 \%)$ & 0 & $255(24.4 \%)$ & $45(4.1 \%)$ \\
\hline a victim of a cime (robery) & $876(80.9 \%)$ & 0 & $194(17.9 \%)$ & $13(1.2 \%)$ \\
\hline harrassed & $886(81.8 \%)$ & 0 & $197(18.2 \%)$ & 0 \\
\hline
\end{tabular}

Residential stability (SR) focused on the period of time (measured in years) they have lived at the current address. It is a quantitative variable, ranging from 0 to $19(\mathrm{M}=10.77, \mathrm{SD}=4.57)$. 
Figure 1. Dispersion of the Residential Stability $(N=1115)$

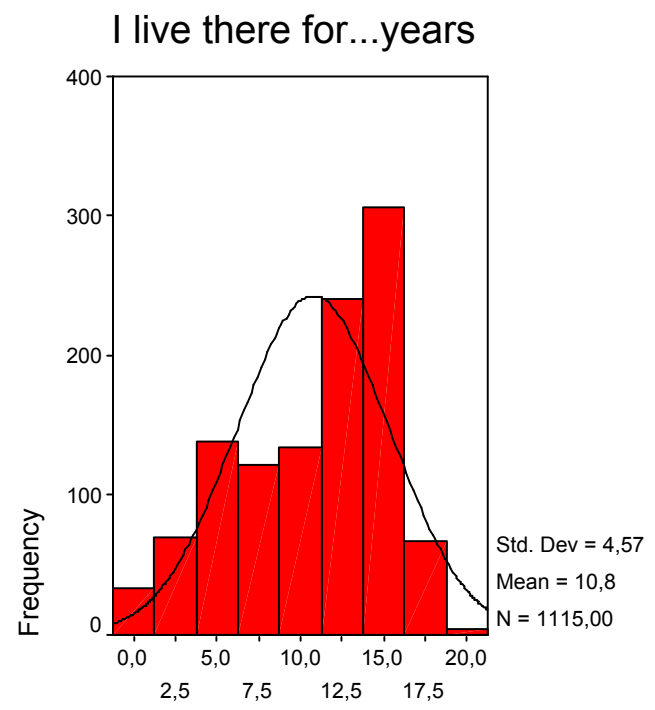

Community resources $(R C)$ index was composed by three subscales: educational resources, medical resources and cultural resources. The number of yes responses from the scales was tallied to create an index ranging from 0 to 7 , with higher numbers representing more community resources available. The Cronbach' alpha for the CR scale was 0.5754 .

Table 3. Descriptive Statistics for Community Resources (N=1142)

\begin{tabular}{ll}
\hline In your neighborhood there is.. & N (\%) \\
\hline a hospital & $661(57.9)$ \\
\hline a school & $1082(94.7)$ \\
\hline a cinema & $584(51.1)$ \\
\hline a theatre & $235(20.6)$ \\
\hline a park & $882(77.2)$ \\
\hline a football, basketb all's port court & $919(80.5)$ \\
\hline a church & $1107(96.9)$ \\
\hline
\end{tabular}

\section{Dependent variables}

Psychological abuse (PA) was conceptualized in behaviours like 'yelling', 'using a nickname', 'cursing', 'humiliation', 'threatening', etc. The 
response categories were 'many times', 'sometimes', 'never' and 'not in the last year, but it happened'. Each response was recoded from 1 to 4 . By adding the scores from each question a total score for PA was generated. The Cronbach' alpha for the PA scale was 0.8042 .

Physical abuse (FA) was conceptualized in behaviours like 'hitting', 'beating'. The response categories were 'many times', 'sometimes', 'never' and 'not in the last year, but it happened'. Each response was recoded from 1 to 4 . By adding the scores from each question a total score for FA was generated. The Cronbach' alpha for the FA scale was 0.7397.

Child Abuse (CA) was composed by items from PA, FA and SA. By adding the scores from these three subscales, a total score was generated. The Cronbach' alpha for the CA scale was 0.7653 .

Neglect (NGL) was defined as the failure of the adult to assure the child the necessary resources for a proper development. The indicators were food neglect, clothing neglect, medical neglect and emotional neglect. The response categories were 'many times', 'sometimes', 'never' and 'not in the last year, but it happened'. Each response was associated to a code from 4 to 1 , and by adding the individual scores a total score was generated which indicated the NGL amplitude. The interval validity for the NGL scale was of 0.7804 .

\section{Demographic control variables}

In the last part, the adolescents identified other familial and personal attributes like gender, year of study, family structure and income, educational and occupational status of their family. The demographic variables were entered as dummy variables in the regression analysis.

\section{Data analysis}

Two stages of data analysis were conducted using SPSS 10.5. In the first stage, one-way ANOVA and pairwise contrasts were used to determine if there were any significant mean differences to the independent variables among students grouped by gender, school level, family type, religion, 
race/ethnicity, income, parents' educational and occupational status. A .05 level of statistical analysis were used to define significant mean differences.

OLS analyses were used in the second stage to compare the relative contribution of four blocks of variables (demographics, community violence, community resources and residential stability) to the outcomes variables (child abuse, psychological abuse, physical abuse and neglect). From the demographic variables religion and ethnicity were excluded because they had no relevance for the sample we've selected. The others were coded as dummies and regressed on the first block. We need to notice thou that the coefficient might be inflated by this strategy. However, this strategy is considered a more efficient approach and potentially one with greater explanatory validity than simultaneous regression strategy. Four steps were used in regression analysis for each of the outcome variables. Eight demographic variables were entered in the first block (defined as 'individual' - gender, year of study and 'family' - type, income, education and occupation). Residential stability was added in the second step, community resources in the third one. In the final step, the full model was tested, including the simultaneous examination of all demographic and community variables. For all the models, the VIF values are well below 10 and the tolerance statistics are well above .2; therefore we can safely conclude that there is no colinearity within our used data (Field 2005). The contributions of individual predictors are discussed only in the presentation of the full model. A .05, 0.1 and .001 levels of statistical significance were used to evaluate the results of the regression analysis.

\section{Results}

\section{Stage 1 Analysis: Means Comparisons}

Table 4 presents the results of the first stage of analysis. Significant mean differences were found for more demographic variables for each independent variable. Patterns of these differences indicated the profile of children who are most likely to encounter danger in their community, who are most likely to access different economical or social resources and who have a variable residential status. It should be noticed that the standard 
deviations of the measures tended to be smaller than the means, suggesting little variation within the groups.

Table 4. Means and Standard Deviations for Measures of Community Violence, Residential Stability and Community Resources

\begin{tabular}{|c|c|c|c|c|c|c|}
\hline & \multicolumn{2}{|c|}{$\mathrm{CV}$} & \multicolumn{2}{|c|}{ RS } & \multicolumn{2}{|c|}{$\mathrm{CR}$} \\
\hline & $\mathrm{M}$ & SD & $\mathrm{M}$ & SD & $\mathrm{M}$ & SD \\
\hline \multicolumn{7}{|l|}{ Gender } \\
\hline Male & 8.36 & 2.94 & 10.58 & 4.73 & $5.13^{\mathrm{a}}$ & 1.39 \\
\hline Female & 8.53 & 3.48 & 10.94 & 4.41 & $4.59^{\mathrm{a}}$ & 1.50 \\
\hline \multicolumn{7}{|l|}{ School level } \\
\hline Middle & $7.67^{\mathrm{a}}$ & 2.66 & $9.79^{\mathrm{a}}$ & 3.98 & $5.04^{4}$ & 1.54 \\
\hline High & $9.36^{\mathrm{a}}$ & 3.58 & $11.97^{\mathrm{a}}$ & 4.94 & $4.61^{\mathrm{s}}$ & 1.35 \\
\hline \multicolumn{7}{|l|}{ Family type } \\
\hline Parents are married & $8.28^{\mathrm{a}}$ & 3.13 & $11.01^{\mathrm{a}}$ & 4.42 & 4.80 & 1.51 \\
\hline Parents are living together but are not & 6.00 & .00 & 14.00 & .00 & 5.00 & .00 \\
\hline married & $9.30^{\mathrm{a}}$ & 3.72 & 10.30 & 4.65 & 4.91 & 1.32 \\
\hline Parents are divorced & 8.87 & 3.08 & $11.50^{\mathrm{a}}$ & 5.72 & 5.29 & 1.36 \\
\hline One of the parents is dead & 9.12 & 6.92 & 8.97 & 4.97 & 4.89 & 1.40 \\
\hline $\begin{array}{l}\text { One of the parents is at work outside the } \\
\text { country }\end{array}$ & 9.10 & 3.04 & 9.65 & 5.04 & 5.03 & 1.21 \\
\hline One of the parents is not my natural parent & & & & & & \\
\hline \multicolumn{7}{|l|}{ Religion } \\
\hline Orthodox & $8.41^{*}$ & 3.17 & $10.79^{2}$ & 4.56 & 4.84 & 1.47 \\
\hline Other & $19.00^{2}$ & .00 & $5.00^{2}$ & .00 & 6.00 & .00 \\
\hline \multicolumn{7}{|l|}{ Race/ethnicity } \\
\hline Romanian & 8.45 & 3.23 & 10.76 & 4.57 & 4.85 & 1.47 \\
\hline Rroma & 7.00 & .00 & 15.00 & .00 & 3.00 & .00 \\
\hline \multicolumn{7}{|l|}{ Income } \\
\hline$<500 \mathrm{RON}$ & $9.61^{2}$ & 4.22 & 9.97 & 5.52 & 4.95 & 1.52 \\
\hline 501-1000 RON & $8.05^{b}$ & 2.69 & 1.73 & 5.13 & $4.43^{\mathrm{a}}$ & 1.41 \\
\hline $1001-1500 \mathrm{RON}$ & 8.60 & 2.76 & $11.41^{\mathrm{a}}$ & 3.83 & $4.64^{\mathrm{b}}$ & 1.64 \\
\hline $1501-2000 \mathrm{RON}$ & $9.04^{b, c}$ & 3.74 & 11.00 & 4.68 & $4.74^{\mathrm{c}}$ & 1.41 \\
\hline$>2001 \mathrm{RON}$ & $8.13^{\text {af }}$ & 3.10 & $10.09^{\mathrm{a}}$ & 4.54 & $5.13^{\mathrm{a}, \mathrm{b}, \mathrm{c}}$ & 1.40 \\
\hline \multicolumn{7}{|l|}{ Occupation status - father } \\
\hline Working full-time & 8.49 & 3.31 & $10.46^{\mathrm{a}, \mathrm{b}}$ & 4.68 & $4.94^{\mathrm{s}}$ & 1.41 \\
\hline Working part-time & 7.83 & 2.28 & 11.44 & 3.41 & $3.56^{\mathrm{a}, \mathrm{b}, \mathrm{c}}$ & 1.26 \\
\hline Looking for job & 8.33 & 2.59 & $12.96^{\mathrm{a}}$ & 2.67 & $4.71^{\mathrm{b}}$ & 2.28 \\
\hline Does not work & 8.82 & 3.61 & $12.14^{b}$ & 3.99 & $4.86^{\mathrm{c}}$ & 1.42 \\
\hline \multicolumn{7}{|l|}{ Occupation status - mother } \\
\hline Working full-time & 8.52 & 3.30 & $10.73^{\mathrm{a}}$ & 4.63 & $5.07^{\mathrm{a}, \mathrm{b}, \mathrm{c}}$ & 1.39 \\
\hline Working part-time & 8.12 & 3.49 & $9.58^{\mathrm{b}}$ & 4.12 & $3.88^{\mathrm{a}}$ & 1.65 \\
\hline Looking for job & 9.25 & 3.38 & $12.89^{a, b}$ & 3.42 & $3.97^{\mathrm{b}}$ & 1.21 \\
\hline Does not work & 7.99 & 2.71 & 10.81 & 4.62 & $4.37^{\mathrm{c}}$ & 1.52 \\
\hline \multicolumn{7}{|l|}{ Educational status - father } \\
\hline $\begin{array}{l}\text { Below highschool } \\
\text { Bas }\end{array}$ & $9.55^{\mathrm{a}}$ & 4.64 & $11.49^{4, b}$ & 4.17 & 4.87 & 1.19 \\
\hline Highschool & $8.06^{\mathrm{ab}}$ & 2.86 & $11.11^{\mathrm{c}, \mathrm{d}}$ & 4.59 & 4.79 & 1.47 \\
\hline University studies & $8.98^{\mathrm{b}}$ & 3.51 & $9.93^{4 f}$ & 4.32 & 4.99 & 1.58 \\
\hline Postuniversity studies & 8.78 & 2.56 & $8.32^{\mathrm{bd}}$ & 5.14 & 5.10 & 1.31 \\
\hline \multicolumn{7}{|l|}{ Educational status - mother } \\
\hline Below highschool & $10.35^{\mathrm{ab}, c, \mathrm{~d}}$ & 4.62 & $12.92^{\mathrm{a}, \mathrm{b}, \mathrm{d}}$ & 4.51 & $4.50^{\mathrm{a}}$ & 1.66 \\
\hline Highschool & $8.09^{b p}$ & 2.75 & $11.12^{\mathrm{b}, e}$ & 4.59 & 4.82 & 1.41 \\
\hline University studies & $8.96^{\mathrm{c}, \mathrm{e}}$ & 3.97 & $9.80^{c, e}$ & 3.96 & 4.97 & 1.56 \\
\hline Postuniversity studies & $8.55^{\mathrm{d}}$ & 2.41 & $8.54^{\mathrm{d}}$ & 5.13 & $5.23^{\mathrm{a}}$ & 1.28 \\
\hline
\end{tabular}

Note: Unique superscripts indicate pairwise contrasts that are significantly different from each other (alpha< .05).

Data from the table 4 reveal that (a) boys were more likely to report a better access to community resources; (b) high school students were more likely to report higher community violence while middle ones had better access to community resources and a low residential stability; (c) those with 
income below 500 RON had significantly higher means at community violence while those with income over $2000 \mathrm{RON}$ reported better access to community resources and a low residential stability; (d) those from atypical family structures (like unmarried parents and divorced) reported high community violence and an increased residential stability; (e) the occupational status of the parents is associated with the access to community resources and with residential stability; (f) those coming from families where parent have little education are more likely to report community violence, while those who come from families with post university studies have the lowest residential stability. Meanwhile, the mother's education status is associated with the level of community resources.

\section{Stage 2 Analysis: Multiple Regressions}

The second stage of analysis included multiple regressions of child maltreatment variables on the three measures of community. Results are presented in tables 5-8.

\section{Child Abuse}

Table 5 presents regression statistics for the prediction of child abuse from the demographic variables and measures of community. In the first step, the demographic variables had a significant effect on Child Abuse, explaining $5.6 \%$ of its variance. By adding $S R$ and $R C$, the $\mathrm{R}^{2}$ did not significantly change. With all demographic and community variables included we obtain an explanation of $27.2 \%$ of the total variance. The full model is statistically significant $\left(\mathrm{F}_{11,937}=32.24\right)$.

Beta weights in the final step indicate the contribution of each variable to the regression equation. Individual variables seem to lose their effect to AC. Out of the family variable, only the type is significant. The $b$ coefficient is -1.97 , meaning that, if all other variables are kept constant, children from monoparental families score on average 2 points higher on the CA scale. The greatest effect on child abuse belongs the community violence $(\beta=.498)$. The effect is in the expected direction: child abuse is more frequent perceived by 
children in the communities where they also perceive a high level of street violence.

Table 5. OLS Analysis Predicting Child Abuse

\begin{tabular}{|c|c|c|c|c|c|c|c|c|}
\hline \multirow[t]{2}{*}{ Variable } & \multicolumn{2}{|c|}{ Step 1} & \multicolumn{2}{|c|}{ Step 2} & \multicolumn{2}{|c|}{ Step 3} & \multicolumn{2}{|c|}{ Step 4} \\
\hline & B & Beta & $\mathrm{b}$ & Beta & $\mathrm{b}$ & Beta & $\mathrm{b}$ & Beta \\
\hline Gender $(0=$ female $)$ & -0.18 & -.01 & -0.19 & -.01 & -0.11 & -.006 & -0.17 & -.01 \\
\hline $\begin{array}{l}\text { School year }(0=\text { middle } \\
\text { school })\end{array}$ & -2.82 & $-.15^{* * *}$ & -2.77 & $-.15^{* * *}$ & -2.75 & $-.15^{* * *}$ & -0.05 & -.003 \\
\hline $\begin{array}{l}\text { Family } \\
(0=\text { monoparentality })\end{array}$ & -2.98 & $-.13^{* * *}$ & -3.01 & $-.13^{\star * *}$ & -3.00 & $-.13^{* * *}$ & -1.97 & $-.08^{* *}$ \\
\hline $\begin{array}{l}\text { Income }(0=\text { below } 2000 \\
\text { RON) }\end{array}$ & -1.76 & $-.09^{* *}$ & -1.76 & $-.09^{* *}$ & -1.70 & $-.09^{* *}$ & -0.57 & -.03 \\
\hline $\begin{array}{l}\text { Education father } \\
\text { (0=below high school) }\end{array}$ & 0.41 & .02 & 0.41 & .02 & 0.40 & .02 & 1.39 & .07 \\
\hline $\begin{array}{l}\text { Education mother } \\
\text { ( } 0=\text { below high school) }\end{array}$ & 0.81 & .04 & 0.79 & .04 & 0.83 & .04 & 0.89 & .04 \\
\hline $\begin{array}{l}\text { Occupation father } \\
(0=\text { not active })\end{array}$ & 1.36 & .04 & 1.38 & .04 & 1.41 & .04 & 1.48 & .05 \\
\hline $\begin{array}{l}\text { Occupation mother } \\
(0=\text { not active })\end{array}$ & -1.01 & -.04 & -1.01 & -.04 & -0.89 & -.03 & -0.95 & -.04 \\
\hline SR & & & 0.01 & .01 & $\begin{array}{c}0.00 \\
2\end{array}$ & .001 & 0.01 & .006 \\
\hline $\mathrm{RC}$ & & & & & -0.23 & -.039 & -0.12 & -.02 \\
\hline $\mathrm{VC}$ & & & & & & & 1.04 & $.49^{* * *}$ \\
\hline $\mathrm{R}^{2}$ & & .056 & & .055 & & .056 & & .272 \\
\hline F & & 8.07 & & 7.17 & & 6.60 & & 32.24 \\
\hline $\mathrm{df}$ & & 8,940 & & 9,939 & & 10,938 & & 11,937 \\
\hline
\end{tabular}

Note: $\mathrm{R}^{2}=.056$ for Step $1 ; \Delta \mathrm{R}^{2}=.000$ for Step $2 ; \Delta \mathrm{R}^{2}=.001$ for Step $3 ; \Delta \mathrm{R}^{2}=.215$ for Step $4 .{ }^{*} \mathrm{p}<.05$, ${ }^{* *} \mathrm{p}<.01,{ }^{* * *} \mathrm{p}<.001$

Beta weights in the final step indicate the contribution of each variable to the regression equation. Individual variables seem to lose their effect to AC. Out of the family variable, only the type is significant. The b coefficient is -1.97 , meaning that, if all other variables are kept constant, children from monoparental families score on average 2 points higher on the CA scale. The greatest effect on child abuse belongs the community violence $(\beta=.498)$. The effect is in the expected direction: child abuse is more frequent perceived by children in the communities where they also perceive a high level of street violence. 


\section{Psychological abuse}

Table 6 reveals regression statistics for the prediction of psychological abuse. In the first step, multiple regressions were conducted to investigate the best predictors of PA among demographic variables. When the combination of variables to predict PA included gender, school level, income and parents' education and occupation, $\mathrm{F}_{(8,940)}=8.81, \mathrm{p}<.001$. The combination of variables had a significant effect on PA and explained 6.2\% of its variance. In the final step, PA was regressed on demographics, SR, RC and CV. Table 6 indicates that these four sets of predictors explain $25.4 \%$ of the variance in Psychological abuse.

Table 6. OLS Analysis Predicting Psychological Abuse

\begin{tabular}{|c|c|c|c|c|c|c|c|c|}
\hline \multirow[t]{2}{*}{ Variables } & \multicolumn{2}{|c|}{ Step 1} & \multicolumn{2}{|c|}{ Step 2} & \multicolumn{2}{|c|}{ Step 3} & \multicolumn{2}{|c|}{ Step 4} \\
\hline & $\mathrm{B}$ & Beta & $\mathrm{b}$ & Beta & $\mathrm{b}$ & Beta & $\mathrm{b}$ & Beta \\
\hline $\begin{array}{l}\text { Gender }(0= \\
\text { females })\end{array}$ & -0.34 & -.02 & -0.35 & -.02 & -0.27 & -.02 & -0.31 & -.02 \\
\hline $\begin{array}{l}\text { School year } \\
(0=\text { middle school })\end{array}$ & -2.41 & $-.19^{* * * *}$ & -2.28 & $-.18^{* * *}$ & -2.26 & $-.17^{* \star * *}$ & -0.48 & -.03 \\
\hline $\begin{array}{l}\text { Family } \\
(0=\text { monoparental. })\end{array}$ & -2.30 & $-.14^{* * *}$ & -2.39 & $-.14^{* * *}$ & -2.37 & $-.14^{* * *}$ & -1.69 & $-.10^{* * *}$ \\
\hline $\begin{array}{l}\text { Income }(0=\text { below } \\
2000 \text { RON })\end{array}$ & -0.73 & -.05 & -0.73 & -.05 & -0.67 & -.05 & 0.07 & .006 \\
\hline $\begin{array}{l}\text { Education father } \\
(0=\text { below HS) }\end{array}$ & 0.37 & .02 & 0.36 & .02 & 0.34 & .02 & 1.00 & $.07^{*}$ \\
\hline $\begin{array}{l}\text { Education mother } \\
(0=\text { below HS })\end{array}$ & 0.55 & .04 & 0.50 & .03 & 0.55 & .04 & 0.59 & .04 \\
\hline $\begin{array}{l}\text { Occupation father } \\
(0=\text { not active })\end{array}$ & 1.41 & $.06^{*}$ & 1.48 & .07 & 1.52 & $.07^{*}$ & 1.56 & $.07^{*}$ \\
\hline $\begin{array}{l}\text { Occupation mother } \\
(0=\text { not active })\end{array}$ & -0.25 & -.01 & -0.24 & -.01 & -0.12 & -.008 & -0.16 & -.01 \\
\hline SR & & & 0.05 & .04 & 0.04 & .03 & 0.04 & .03 \\
\hline $\mathrm{RC}$ & & & & & -0.24 & -.05 & -0.16 & -.03 \\
\hline $\mathrm{VC}$ & & & & & & & 0.69 & $.46^{* * *}$ \\
\hline $\mathrm{R}^{2}$ & & .062 & & .062 & & .064 & & .254 \\
\hline $\mathrm{F}$ & & 8.81 & & 8.02 & & 7.52 & & 30.34 \\
\hline $\mathrm{df}$ & & 8,940 & & 9,939 & & 10,938 & & 11,937 \\
\hline
\end{tabular}

Note: $R^{2}=.062$ for Step $1 ; \Delta R^{2}=.002$ for Step $2 ; \Delta R^{2}=.003$ for Step $3 ; \Delta R^{2}=.188$ for Step $4 .{ }^{*} p<.05$, ${ }^{* *} \mathrm{p}<.01,{ }^{* * *} \mathrm{p}<.001$ 
This time also individual variables (gender and school year) have no significant effect on AP. But in this case family variables interfere. The $b$ coefficient from final step shows us that monoparentality is a risk factor for psychological abuse. Children belonging to these structures scoring on average 1.69 higher on PA scale (if other variables are kept constant). Similarly 'father' seems to be an explanatory variable of PA. Children whose fathers have higher studies $(b=1)$ and are active in the work filed $(b=1.56)$ are defined as risk factors for our sample. Out of community variables only VC is significant $(\beta=0.466)$. Also, as expected, more community violence is perceived, more psychological abuse is felt within the families from urban areas.

\section{Physical abuse}

Table 7 presents regression statistics for the prediction of physical abuse. In the first step, the demographic variables had a significant effect on FA, explaining $3.9 \%$ of its variance. In Step 2, the measure of residential stability was added significantly to the prediction of PA, explaining an additional $0.4 \%$ of its variance. $4.3 \%$ of the variance was explained. In step 3 and 4, after adding $\mathrm{RC}$ and $\mathrm{VC}$, there was an increase of $16 \%$, the total variance explained by the equation reaching $20.4 \%$.

In the full model, it was again possible to evaluate the unique contribution of each variable from the equation. The $b$ coefficient shows that if all other variables remain constant, children whose mothers are active in the work field score on average nearly 1 point higher on the FA scale, compared to those whose mothers are unemployed. Similarly, by controlling all other variables children from families with an income below 2000 RON are also at risk from physical abuse $(b=-0.66)$. Individual variables are not important in this case. Out of community variables only community resources are not significantly involved in the regression model. SR and VC act in the expected direction: in urban communities where there is a high level of community violence $(\beta=.430)$ and low residential stability $(\beta=-.065)$ there is a high level of physical abuse (according to children's perceptions). 
Table 7. OLS Analysis Predicting Physical Abuse

\begin{tabular}{|c|c|c|c|c|c|c|c|c|}
\hline \multirow[t]{2}{*}{ Variables } & \multicolumn{2}{|c|}{ Step 1} & \multicolumn{2}{|c|}{ Step 2} & \multicolumn{2}{|c|}{ Step 3} & \multicolumn{2}{|c|}{ Step 4} \\
\hline & $B$ & Beta & $\mathrm{b}$ & Beta & $\mathrm{b}$ & Beta & $\mathrm{b}$ & Beta \\
\hline Gender ( $0=$ female) & 0.15 & .02 & 0.15 & .02 & 0.15 & .02 & 0.13 & .02 \\
\hline $\begin{array}{l}\text { School year } \\
(0=\text { middle school })\end{array}$ & -0.42 & $-.06^{*}$ & -0.52 & $-.07^{* *}$ & -0.52 & $-.07^{*}$ & 0.34 & .05 \\
\hline $\begin{array}{l}\text { Family } \\
(0=\text { monoparental. })\end{array}$ & -0.64 & $-.04^{*}$ & -0.56 & $-.06^{*}$ & -0.56 & $-.06^{*}$ & -0.19 & -.02 \\
\hline $\begin{array}{l}\text { Income }(0=\text { below } \\
2000 \text { RON })\end{array}$ & -0.99 & $-.14^{* * *}$ & -0.99 & $-.14^{\star * *}$ & -0.99 & $-.14^{* * *}$ & -0.66 & $-.09^{* *}$ \\
\hline $\begin{array}{l}\text { Education father } \\
(0=\text { below HS) }\end{array}$ & 0.12 & .01 & 0.15 & .02 & 0.15 & .02 & 0.50 & .06 \\
\hline $\begin{array}{l}\text { Education mother } \\
(0=\text { below HS })\end{array}$ & 0.10 & .01 & 0.13 & .01 & 0.13 & .01 & 0.09 & .01 \\
\hline $\begin{array}{l}\text { Occupation father } \\
(0=\text { not active })\end{array}$ & 0.09 & .009 & 0.02 & .002 & 0.02 & .002 & 0.02 & .003 \\
\hline $\begin{array}{l}\text { Occupation mother } \\
(0=\text { not active })\end{array}$ & -0.78 & $-.09^{* *}$ & -0.77 & $-.09^{* *}$ & -0.77 & $-.08^{* *}$ & -0.88 & $-.10^{* * *}$ \\
\hline SR & & & -.05 & $-.06^{*}$ & -0.05 & $-.07^{*}$ & -0.04 & $-.06^{*}$ \\
\hline $\mathrm{RC}$ & & & & & $\begin{array}{c}-0.01 \\
\end{array}$ & $\begin{array}{l}.005 \\
\end{array}$ & 0.03 & .01 \\
\hline $\mathrm{VC}$ & & & & & & & 0.34 & $.43^{* * *}$ \\
\hline $\mathrm{R}^{2}$ & & .039 & & .043 & & .042 & & .204 \\
\hline $\mathrm{F}$ & & 5.99 & & 5.83 & & 5.24 & & 23.82 \\
\hline $\mathrm{df}$ & & 8,969 & & 9,968 & & 10,967 & & 11,966 \\
\hline
\end{tabular}

Note: $R^{2}=.039$ for Step $1 ; \Delta R^{2}=.004$ for Step $2 ; \Delta R^{2}=.000$ for Step $3 ; \Delta R^{2}=.162$ for Step $4 .{ }^{*} p<.05$, ${ }^{* *} \mathrm{p}<.01,{ }^{* * *} \mathrm{p}<.001$

\section{Neglect}

Table 8 presents regression statistics for the prediction of neglect. In the first step, multiple regressions were conducted to investigate the best predictors of NGL among demographic variables. The combination of demographic variables had a significant effect on the NGL $\left(\mathrm{F}_{8}, 961=10.43\right.$, $\mathrm{p}<.001$ ), explaining $7.2 \%$. In the next step, the measure of SR was added to the equation. By adding the all three measures of the community in the final step the explanatory value reached $19.5 \%$.

All community variables are significant to the prediction equation. The greatest beta is for VC $(\beta=0.352)$, followed by SR $(\beta=-0.100)$ and $R C(\beta=-$ $0.084)$. The effects are in the expected direction: neglect is determined by a 
high level of community violence, by low community resources and by low residential stability. Out of the individual variables, the $b$ coefficient shows that, if other variables are constant, girls score on average 0.66 higher on NGL scale. Similarly, risk factors for neglect are monoparentality status of the family and the superior studies of mothers.

Table 8. OLS Analysis Predicting Neglect

\begin{tabular}{|c|c|c|c|c|c|c|c|c|}
\hline \multirow[t]{2}{*}{ Variables } & \multicolumn{2}{|c|}{ Step 1} & \multicolumn{2}{|c|}{ Step 2} & \multicolumn{2}{|c|}{ Step 3} & \multicolumn{2}{|c|}{ Step 4} \\
\hline & $\mathrm{b}$ & Beta & $\mathrm{b}$ & Beta & $\mathrm{b}$ & Beta & $\mathrm{b}$ & Beta \\
\hline Gender ( $0=$ female $)$ & -0.67 & $-.14^{* * *}$ & -0.68 & $-.14^{* \star *}$ & -0.62 & $-.13^{\star * * *}$ & -0.64 & $-.13^{* \star *}$ \\
\hline $\begin{array}{l}\text { School year } \\
(0=\text { middle school })\end{array}$ & -0.72 & $-.15^{* * *}$ & -0.81 & $-.17^{* \star *}$ & -0.79 & $-.16^{* * *}$ & -0.29 & $-.06^{*}$ \\
\hline $\begin{array}{l}\text { Family } \\
(0=\text { monoparental. })\end{array}$ & -0.94 & $-.15^{* * * *}$ & -0.88 & $-.14^{\star \star *}$ & -0.87 & $-.14^{* \star *}$ & -0.66 & $-.11^{* * *}$ \\
\hline $\begin{array}{l}\text { Income }(0=\text { below } \\
2000 \mathrm{RON})\end{array}$ & 0.08 & .01 & 0.08 & .01 & 0.11 & .02 & 0.30 & $.06^{*}$ \\
\hline $\begin{array}{l}\text { Education father } \\
(0=\text { below HS) }\end{array}$ & -0.11 & -.02 & -0.08 & -.01 & -0.09 & -.01 & 0.10 & .02 \\
\hline $\begin{array}{l}\text { Education mother } \\
\text { ( } 0=\text { below HS) }\end{array}$ & 0.65 & $.12^{* *}$ & 0.67 & $.13^{* *}$ & 0.70 & $.13^{\text {*** }}$ & 0.68 & $.13^{* * *}$ \\
\hline $\begin{array}{l}\text { Occupation father } \\
(0=\text { not active })\end{array}$ & -0.05 & -.008 & -0.12 & -.01 & -0.11 & -.01 & -0.11 & -.01 \\
\hline $\begin{array}{l}\text { Occupation mother } \\
(0=\text { not active })\end{array}$ & 0.10 & .01 & 0.11 & .01 & 0.19 & .03 & 0.13 & .02 \\
\hline SR & & & -0.04 & $-.08^{* *}$ & -0.05 & $-.10^{* *}$ & -0.05 & $-.10^{* \star *}$ \\
\hline $\mathrm{RC}$ & & & & & -0.16 & $-.09^{* *}$ & -0.13 & $-.08^{* *}$ \\
\hline $\mathrm{VC}$ & & & & & & & 0.19 & $.35^{\star \star *}$ \\
\hline $\mathrm{R}^{2}$ & & .072 & & .078 & & .086 & & .195 \\
\hline $\mathrm{F}$ & & 10.43 & & 10.08 & & 10.09 & & 22.34 \\
\hline $\mathrm{df}$ & & 8,961 & & 9,960 & & 10,959 & & 11,958 \\
\hline
\end{tabular}

Note: $R^{2}=.072$ for Step $1 ; \Delta R^{2}=.006$ for Step $2 ; \Delta R^{2}=.009$ for Step $3 ; \Delta R^{2}=.109$ for Step $4 .{ }^{*} p<.05$, ${ }^{* *} \mathrm{p}<.01,{ }^{* * *} \mathrm{p}<.001$

\section{Discussion}

Although interesting, results should be carefully understood because one of the most serious limits deals the sampling procedure. Data was collected in schools and most of the respondents were coming from "typical family structures" (with both parents who are married, as was defined). The sample selection can bias the results and due to the selection procedure an 
important part of children's population which is more exposed to violence and abuses it is not investigated. Generally speaking, children who do not attend school but are of school age, are more exposed to violence and abuse because they are living in poor families and/or disorganized families (both being factors which increase the likelihood of violent behaviour against children). The sampling method has a serious impact on both the results of the analysis and on the conclusion which can be drawn from the study. Firstly, the results are restricted to a population which is less exposed to violent behaviour. Secondly, the population under investigation is not that of children living in Vâlcea County. Also, the data analysis strategy might result in an inflation of $\mathrm{R}^{2}$.

But still, the study shows that the communities in which children and their families live constitute an important factor in child maltreatment. Then, child abuse is not an individual or isolated family problem but a community one, most often related to the social and economic situation of the locale. While the roots of the problem are complex, this study has attempted to uncover the social factors required to develop programs of prevention and intervention needed by children and their families. In terms of proposed hypothesis, community violence indeed correlated with increased child abuse reports. These results are consisting with previous research that shows that high rates of community violence leads to individual violence, in this case toward children (Molnar et al. 2003).

Another explicative pathway in child maltreatment behaviours included residential stability. According to previous studies (Molnar et al. 2003), our results also showed that residential stability did not have any effect on child abuse. The explanation may lay in the social conditions themselves, which did not allow a constant change of address. Most families live in the same apartment since the beginning (the communist era).

Social resources are an important factor of the community. In their review of research on the effects of poor neighbourhoods on children and adolescents, Mayer and Jencks (1989) concluded that the evidence is quite mixed. When family and individual characteristics are controlled neighbourhood economic status often has weak effects (Coulton \& Pandey 1992; Tolan, Gorman-Smith and Henry 2006). On the other hand, Drake and Pandey (1996) explored the association between neighbourhood poverty 
levels and the number of substantiated reports of various forms of child maltreatment. They found that maltreatment was significantly related to the degree of poverty within each identified neighbourhood. Of the three forms of abuse examined (neglect, physical abuse, sexual abuse), neglect was most closely associated with community-wide poverty. Our findings did not reflect any association between poverty and child abuse. The quality and availability of resources within the community for supporting parents is another important factor. High-risk communities may be less likely to have the medical, mental health, and social service resources needed by parents. Furthermore, the resources that do exist within their community may already be overburdened. The community resource pathway is supported by previous research showing differences in the availability and utilization of resources by parents in high-risk neighbourhoods (Garbarino \& Sherman 1980). Our results showed that the low availability of community resources (medical, educational and recreational) is associated with increased child abuse, and especially to psychological abuse.

The last hypotheses tried to relate child abuse with some personal characteristics of the victim. The variables that revealed significant associations were 'family type', 'educational status' and 'occupational status'. Certain family structure's characteristics have been associated with child abuse, and especially with physical abuse. Our findings show that in atypical family structures there is a greater risk for child abuse. Actually, current non-medical literature documents that recent changes in family structure increases the risk of child abuse (Lamb 2001; Oliver, Kuhns \& Pomeranz 2006). In a two parent home, ideally, there is a sharing of the physical and psychological demands of the child. Usually a greater portion of these needs is met by one parent or the other, maintaining the balance of family functioning. Nowadays, the atypical family structures (e.g. parents divorced, parents living together, but not married, parent that is working outside the country) puts a supplementary child-care-burden over the remaining parent increasing in this way the frequency of maltreatment behaviours.

Although, the parent's education is an important explanatory variable (Coulton et al. 1999), one interesting finding of our study is the role of fathers' education in child abuse. Little father education was associated with 
increased physical and psychological abuse and the occupational status if the father was related with psychological abuse. Previous research had documented the role of male figure in child abuse rate (Lamb 2001; Oliver, Kuhns and Pomeranz 2006), but still how the relation works is not fully understood. Then father occupational status was important in explaining physical and psychological abuse. Previous studies examining a child's "career" in the child welfare system found that male unemployment was highly correlated with physical abuse (Gillham et al. 1998; Freisthler, Merritt and La Scala 2006). They concluded that living in neighbourhoods with high rates of male unemployment places children at a greater risk of being physically abused. In our society, where there is not a fully equalization of the partners' rights within the family, the father figure seems to be more important than the mother's. Mother is still responsible for child education and care, but father is the one that supervises her.

\section{Implications for practice}

Although previous research has focused on features of individual children and caregivers likely to be involved in family violence, in the last years there has been a move away from this traditional fixation on static features (race, socioeconomic status) towards a focus on multilevel influences, including how certain features of neighbourhood life bring about change in a given phenomenon of interest. This has led to unique attempts to empirically measure social interactional and institutional dimensions that might explain how neighbourhood effects work out in the day-to-day life of communities. Certainly, there is substantial cross-sectional evidence that child maltreatment is related to features of the larger neighbourhood environment. The mechanisms that underlie these relationships have not been fully explored and lead one to ask, "What is it about the environment that may affect the prevalence of child maltreatment?" This question must be addressed and the findings translated into effective intervention efforts. For the moment, most of the prevention activities are based on identifying children/families that are in risk and trying to improve parental abilities or modifying the elements that raises the risk of maltreatment. Such activity takes a considerable effort from the practitioners: on one side, identifying families/children in risk is based on the official records (that may not be 
totally accurate) or on available resources; on the other side, a personcentred method even if successful can not have long term benefits as long as the individual is returning to the same social environment that initially have supported his abusive behaviour. The interventions that manage to change structural factors have higher chances to create a supportive environment for the children. Then, we can not forget that community intervention practices are financially more efficient than individual ones (Freisthler, Merritt and LaScala 2006).

The current analyses have revealed some features of the community and have some practical implications, at least in social work field. Communities with higher level of violence and with little social resources have higher rates of child abuse. It has been suggested that one of the ways to prevent family violence is to meet the needs of families experiencing such community problems (Barnett et al. 1997 apud. Molnar et al. 2003). Our research also suggests that individually targeted prevention efforts may not be the sole means to this end. Programs that reduce neighbourhood-level disadvantage reduce community violence, and increase social networks may all prove effective and efficient means of reducing child abuse.

\section{References:}

Asociația Telefonul Copilului. 2009. Raport anual. http://www. telefonulcopilului.ro/uploaded/rapoarte-anuale/Raport-Anual-2009 .pdf (accessed April 4, 2010).

Berger, Lawrence M. 2005. Income, family characteristics, and physical violence toward children. Child Abuse \& Neglect 29 (2): 107-133.

Cicchetti, Dante and Kristin Valentino. 2006. An ecological-transactional perspective on child maltreatment: Failure of the average expectable environment and its influence on child development. In Developmental Psychopathology, eds. Dante Cicchetti and Donald J. Cohen (eds.), 129-201. Hoboken: John Wiley \& Sons.

Coulton, Claudia J., Jill E. Korbin and Marilyn Su. 1999. Neighbourhoods and child maltreatment: A multilevel study. Child Abuse and Neglect 23 (11): 1019-1040.

Coulton, Claudia J., Jill E. Korbin, Marilyn Su and Julian Chow. 1995. Community level factors and child maltreatment rates. Child Development 66 (5): 1262-1276. 
Coulton, Claudia J. and Shanta Pandey. 1992. Geographic concentration of poverty and risk to children in urban neighborhoods. American Behavioral Scientist 35 (3): 238-257.

Coulton, Claudia J., David S. Crampton, Molly Irwin, James C. Spilsbury and Jill E. Korbin. 2007. How neighbourhoods influence child maltreatment: A review of the literature and alternative pathways. Child Abuse and Neglect 31 (11-12): 1117-1142.

Deccio, Gary, William C. Horner and Dee Wilson. 1994. High-risk neighborhoods and high-risk families: Replication research related to the human ecology of child maltreatment. Journal of Social Service Research 18 (3-4): 123-137.

Drake, Brett and Shanta Pandey. 1996. Understanding the relationship between neighbourhood poverty and specific types of child maltreatment. Child Abuse and Neglect 20 (11): 1003-1018.

Ernst, Joy S. 2000. Mapping child maltreatment: Looking at neighbourhoods in a suburban county. Child Welfare 79 (5): 555-572.

Ernst, Joy S. 2001. Community-level factors and child maltreatment in a suburban county. Social Work Research 25 (3): 133-142.

Field, Andy. 2005. Discovering Statistics Using SPSS. London: Sage Publications.

Freisthler, Bridget. 2004. A spatial analysis of social disorganization, alcohol access, and rates of child maltreatment in neighbourhoods. Children and Youth Services Review 26 (9): 803-819.

Freisthler, Bridget, Darcey H. Merritt and Elizabeth A. LaScala. 2006. Understanding the Ecology of Child Maltreatment: A Review of the Literature and Directions for Future Research. Child Maltreatment 11 (3), 263-280.

Freisthler, Bridget, Lorraine T. Midanik and Paul J. Gruenewald. 2004. Alcohol outlets and child physical abuse and neglect: Applying routine activities theory to the study of child maltreatment. Journal of Studies on Alcohol 65 (5): 586-592.

Freisthler, Bridget, Barbara Needell and Paul J. Gruenewald. 2005. Is the physical availability of alcohol and illicit drugs related to the neighbourhoods rates of child maltreatment? Child Abuse $\mathcal{E}$ Neglect 29 (9): 1049-1060.

Garbarino, James and Ann Crouter. 1978. Defining the community context for parent-child relations: the correlates with child maltreatment. Child Development 49 (3): 604-616.

Garbarino, James and Kathleen Kostelny. 1992. Child maltreatment as a community problem. Child Abuse E Neglect 16 (4): 455-464.

Garbarino, James and Deborah Sherman. 1980. High-risk neighbourhoods and high-risk families: The human ecology of maltreatment. Child Development 51 (1): 188-198. 
Gillham, Bill, Gary Tanner, Bill Cheyne, Isobel Freeman, Martin Rooney and Allan Lambie. 1998. Unemployment rates, single parent density, and indices of child poverty: Their relationship to different categories of child abuse and neglect. Child Abuse E Neglect 22 (2): 79-90.

Global Initiative to End all Corporal Punishment of Children. 2008. Ending legalized violence against children - Global report. http://www. endcorporalpunishment.org/pages/pdfs/reports/GlobalReport2008 .pdf (accessed November 10, 2009).

Guterman, Neil B., Shawna J. Lee, Catherine A. Taylor and Paul J. Rathouz. 2009. Parental perceptions of neighbourhood processes, stress, personal control, and risk for physical child abuse and neglect. Child Abuse E Neglect 33 (12): 897-906.

Kim, Jin Seok. 2004. Neighbourhood effects on the etiology of child maltreatment: A multilevel study. Dissertation Abstracts International 65 (08): 3157B.

King, Garry, Robert Keohane and Sidney Verba. 2000. Fundamentele cercetării sociale. Iaşi: Polirom.

Kingston, Beverly, David Huizinga and Delbert S. Elliott. 2009. A test of social disorganization theory in high-risk urban neighbourhoods. Youth \& Society 41 (1): 53-79.

Korbin, Jill E., Claudia J. Coulton, Heather Lindstrom-Ufuti and James Spilsbury. 2000. Neighbourhood views of the definition and etiology of child maltreatment. Child Abuse E Neglect 24 (12): 1509-1527.

Korbin, Jill E., Claudia J. Coulton, Sarah Chard, Candis Platt-Houston and Marilyn Su. 1998. Impoverishment and child maltreatment in African American and European American neighbourhoods. Development and Psychopathology 10 (2): 215-233.

Krishnan, Vijaya and Kenneth B. Morrison. 1995. An ecological model of child maltreatment in a Canadian province. Child Abuse E Neglect 19 (1): 101-113.

Lamb, Michael E. 2001. Male Roles in Families "at Risk": The Ecology of Child Maltreatment. Child Maltreatment 6 (4): 310-313.

Lenth, Russell V. 2006. Java Applets for Power and Sample Size. Computer Software. http://www.stat.uiowa.edu/ rlenth/Power/(retrieved April 4, 2010).

Molnar, Beth E., Stephen L. Buka, Robert T. Brennan, John K. Holton and Felton Earls. 2003. A Multilevel Study of Neighbourhoods and Parent-to-Child Physical Aggression: Results From the Project on Human Development in Chicago Neighbourhoods. Child Maltreatment 8 (2): 84-97.

Oliver, William J., Lawrence R. Kuhns and Elaine S. Pomeranz. 2006. Family Structure and Child Abuse. Clinical Pediatrics 45 (2): 111-118.

Pinheiro, Paulo Sérgio. 2006. World Report on Violence against Children. United Nations Secretary-General's Study on Violence against Children. 
Rotariu, Traian, Maria Roth-Szamoskozi, Elemér Mezei, A. Muneanu and V. Sabău. 1996. Expunerea copiilor la abuz şi neglijare în județul Cluj. ClujNapoca: Editura Comprex.

Roth, Maria. 2005. Femei şi copii victime ale violenței. Cluj-Napoca: Presa Universitară Clujeană.

Sampson, Robert J., Jefferey D. Morenoff and Thomas Gannon-Rowley. 2002. Assessing "neighbourhood effects": Social processes and the new directions in research. Annual Review of Sociology 28: 443-478.

Scannapieco, Maria and Kelli Connell-Carrick. 2005. Understanding Child Maltreatment: An Ecological and Developmental Perspective. New York: Oxford University Press.

Smith, Carolyn A., Timothy O. Ireland and Terence P. Thornberry. 2005. Adolescent maltreatment and its impact on young adult social behavior. Child Abuse \& Neglect 29 (10): 1099-1119.

Tolan, Patrick, Deborah Gorman-Smith and David Henry. 2006. Family violence. Annual Review of Psychology 57: 557-583.

Zielinski, David S. and Catherine P. Bradshaw. 2006. Ecological Influences on the Sequel of Child Maltreatment: A Review of the Literature. Child Maltreatment 11 (1): 49-62.

Zuravin, Susan J. 1986. Residential density and urban child maltreatment: An aggregate analysis. Journal of Family Violence 1 (4): 307-323.

Zuravin, Susan J. 1989. The ecology of child abuse and neglect: Review of the literature and presentation of data. Violence and Victims 4 (2): 101-120. 